\title{
Manifestação de recursos poéticos em dois filmes do \\ Cinema Novo ${ }^{1}$
}

\author{
Eduardo Peñuela Cañizal (USP/UNIP) $)^{2}$
}

\section{Resumo}

As considerações que se seguem têm como objetivo levantar uma hipótese de leitura fundamentada no atinente ao papel que alguns recursos retóricos desempenham em Vidas secas e Terra em transe. Além disso, tentarei avaliar o alcance dessas hipóteses através de um exercício de interpretação que me permita estabelecer diferenças na manifestação do poético, entendido no âmbito das ciências da linguagem, nessas duas obras. Para tanto, farei, inicialmente, observações de caráter geral destinadas a esclarecer os pontos básicos em que se apóia a leitura, que mais adiante realizo, de fragmentos dos filmes.

Palavras-chaves: Poética; Vidas Secas; Terra em Transe; ciências da linguagem

\begin{abstract}
The ideas that follow are to raise an hypothesis of how to read Vidas Secas and Terra em Transe based on the role of some rethorical resources present in them. Besides that, I will try to investigate the extent of the hypothesis performing an interpretation exercise. This exercise will allow to set differences in the manifestation of the poetic, undestood in the ground of the language sciences. To such intent I will first draw general considerations to clarify the basic steps in which is supported the reading of fragments of the movies made in the sequence.
\end{abstract}

Keywords: Poetics; Vidas Secas; Terra em Transe; language sciences 
As considerações que se seguem têm como objetivo levantar uma hipótese de leitura fundamentada no atinente ao papel que alguns recursos retóricos desempenham em Vidas secas e Terra em transe. Além disso, tentarei avaliar o alcance dessas hipóteses através de um exercício de interpretação que me permita estabelecer diferenças na manifestação do poético, entendido no âmbito das ciências da linguagem, nessas duas obras. Para tanto, farei, inicialmente, observações de caráter geral destinadas a esclarecer os pontos básicos em que se apóia a leitura, que mais adiante realizo, de fragmentos dos filmes. Quero advertir, entretanto, que meus comentários, mesmo sendo concisos, sempre estarão pautados no pressuposto de que qualquer mensagem audiovisual está formada segundo uma combinatória de signos pertencentes a códigos diferentes: fotografia, gestualidade, sonoplastia, narrativa, vestuário etc.

Dessa perspectiva, o modo de representar e mostrar o mundo, que cada uma das fitas nos oferece, se reveste de particularidades específicas. Visto em seu conjunto, Vidas secas, como se quisesse expressar a secura do romance em que se inspira, põe em jogo um número reduzido de códigos. Ao contrário, a estrutura textual de Terra em transe não só mostra um número mais amplo de códigos, mas também uma exploração mais pormenorizada das peculiaridades expressivas de sistemas como, por exemplo, o pictográfico e o teatral. Essa evidente diferença pode ser entendida de várias maneiras ${ }^{3}$. Meu interesse, no entanto, é o de aproximar-me dela tendo em vista a relevância que a espessura expressiva de cada um dos filmes tem para a atualização da função poética. Desse ângulo, creio que a diferença assinalada desloca, no caso da fita de Nelson Pereira dos Santos, a densidade do ambíguo para os conteúdos que a aparente transparência dos significantes projeta. No que diz respeito à obra de Glauber Rocha, a opacidade dos significantes, porém, esconde os conteúdos e incita o observador ávido pelo entendimento do texto audiovisual a uma participação mais problemática. Ora, admitindo a validez de tais ponderações, amarro-me à idéia de que, tanto uma quanto a outra, constroem um espaço expressivo propício à revelação do poético. Isso porque se, de um lado, a ambigüidade se situa no plano do conteúdo, de outro, a polissemia, decorrente da forma de arranjar os componentes que configuram a expressão, aumenta a abrangência da conotação. 
Assim, se tomarmos como referência a utilização que fazem os dois cineastas do código narrativo, por exemplo, os procedimentos acima assinalados deixam marcas diferentes em cada um dos filmes. Em Vidas secas, a fábula, numa primeira leitura, parece ter sido construída seguindo uma trajetória linear: concatenação de seqüências que se reportam, cronologicamente, a fragmentos da vida dos personagens ${ }^{4}$. Às vezes, nalgumas das seqüências se inserem o que poderíamos chamar de microrelatos, vários deles representando uma espécie de fluir de consciência dos personagens. Mas, no tocante à fábula propriamente dita, isto é, às unidades semânticas que permanecem constantes e cuja sucessão constitui o relato, o filme parece estar centrado numa única dicotomia: a carência e a tentativa de superá-la ${ }^{5}$. Desse ponto de vista, os micro-relatos não afetam propriamente a linearidade da fábula, já que eles têm a missão de caracterizar melhor os personagens conferindo-lhes uma densidade interior. Creio que essa particularidade fica evidente se pensarmos que, através dos códigos da vestimenta e da gestualidade - aspecto físico dos atores -, a maneira mais consistente de atribuir uma dimensão psicológica aos protagonistas da narrativa provém, precisamente, da intromissão dos micro-relatos nos entremeios da dicotomia mencionada.

Essas intromissões provocam, enquanto recursos atrelados à maneira de contar, delongas que não chegam a transpor as fronteiras semânticas da carência e criam, por isso, expectativas a respeito de possíveis alternativas referentes à superação da carência. Além dessa finalidade, o recurso em questão coloca em jogo a utilização de diversos pontos de vista. A ida de Fabiano, Sinhá Vitória, as crianças e Baleia à aldeia, para assistir aos festejos, mostra um conjunto de significados pertencentes a uma pluralidade de eixos semânticos. Sinhá Vitória ataviada com seu vestido novo e sua sombrinha. Fabiano com terno e seus problemas com os sapatos. As crianças uniformizadas e Baleia carregando com alegria seus ímpetos de liberdade. Todos esses elementos transmitem a sensação de que as personagens têm a possibilidade de superar a miséria e se integrar numa vida social mais digna, numa vida social em que a família possa ter outros horizontes. Mas, logo a seguir, toda essa expectativa se desmorona no episódio do Soldado Amarelo, quando Fabiano, injustamente, é encarcerado e chicoteado. E, de repente, o 
espectador do filme fica diante de imagens, palavras e ruídos cujos significados se multiplicam e incrustam na unidade semântica da carência, conteúdos advindos de uma pluralidade de pontos de vista. Ou seja, essa unidade semântica assume formas conotativas em que se implicam significâncias que se prendem à fome, à injustiça, à incivilidade, ao desrespeito e a todo tipo de abusos.

Com base nessas particularidades, julgo ser legítimo, levando em conta a perspectiva teórica aqui adotada, afirmar que o sentido da carência se estende ${ }^{6}$ quando se articula com os significados produzidos pelas ações das personagens. Ele cresce, portanto, cada vez que essas ações marcam os efeitos da falta e, fatalmente, dessa falta emergem ressonâncias dos anseios e, sobretudo, dos desejos. Ademais, esse recurso, sem ser alheio às vicissitudes representadas em que se situam as personagens, contribui para que os espectadores do filme convivam com esses simulacros de interioridade dos seres que todos os protagonistas encarnam. O que quer dizer, entre outras coisas, que os sentidos atribuídos à carência se articulam com os das personagens para instituir processos de significação mais densos e, em determinadas passagens, mais poéticos ${ }^{7}$. Em outro nível, tais significações aumentam sua grandeza quando se juntam com significados que têm sua origem na narração, isto é, na maneira de contar.

Assim, parto do princípio de que a narrativa é um código e se ordena segundo as regras de três níveis: o da fábula, o das personagens e o da maneira de contar. Portanto, ancorado nesse molde, tenho para mim, na esteira dos estudos de narratologia ${ }^{8}$, que a narração constitui a instância em que o narrador, enquanto sujeito manipulador, têm mais possibilidades de desenvolver sua imaginação criativa. Disso se tem prova quando o leitor centra seu interesse não exclusivamente nas peripécias ou no desempenho dos atores, mas também na maneira de arranjar esses elementos, algo que penso deixar claro nos comentários que faço das seqüências inicial e final de Vidas secas. Escolho essas duas porque nelas encontro, sem necessidade de recorrer a outras, particularidades que me permitem ilustrar a questão e propor uma interpretação que esteja de acordo com o modelo posto em prática neste trabalho. 


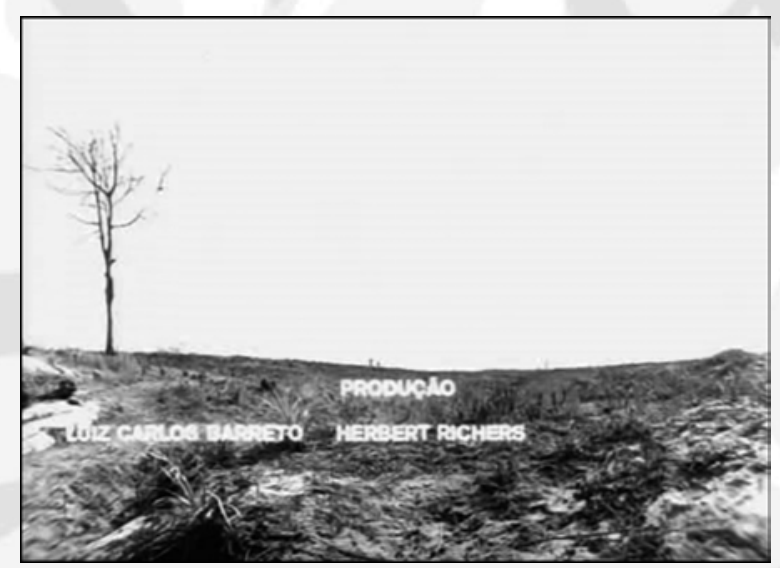

Fotograma do começo

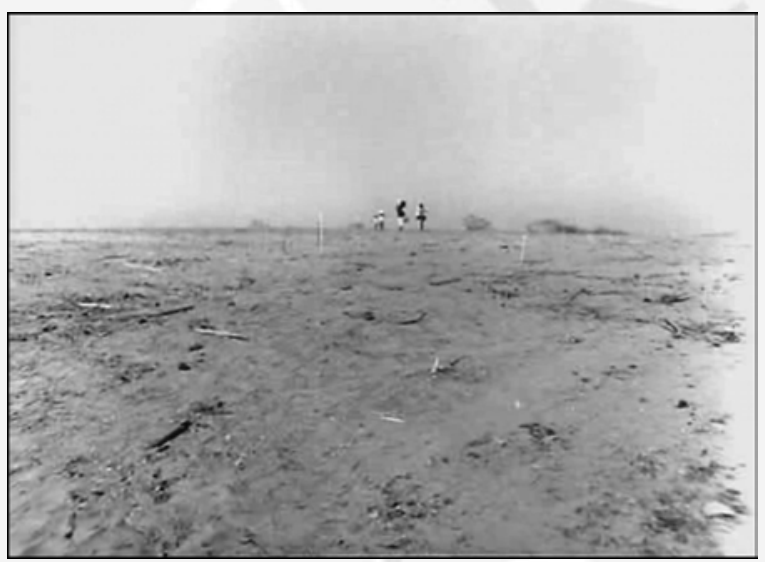

Fotograma do final

Tomando como referencial das duas seqüências os fotogramas acima reproduzidos, gostaria de ressaltar os aspectos simétricos que entre eles existem. Ambos fazem parte de dois pontos opostos na linha sobre a qual se monta a narração e, observando o enquadramento, tanto um plano quanto o outro denunciam que a posição da câmera é correspondente em cada uma das tomadas. Ademais, o movimento das personagens é também oposto: primeiro elas aparecem, diminutas, no horizonte da paisagem e, no fim do filme, elas desaparecem como sombras no agreste. Essa maneira de abrir e fechar a narrativa consente que o trabalho decodificante do espectador atine, independente dos significados já assinalados, com conotações que transcendem a caracterização das personagens e os conteúdos da carência.

Vale dizer que, desse ângulo, a narração de Vidas secas se abre a uma leitura plural e não se pode confundir com o final cerrado do relato. A maneira de contar tem ressonâncias que a mim, em particular, indicam as veredas que 
conduzem até o mito de Sísifo e suas nuanças simbólicas, pois, como se sabe, esta personagem mitológica foi moldada segundo os parâmetros de uma narração pautada nos princípios da simetria: Sísifo foi condenado a rolar, com a força de suas mãos, uma volumosa pedra a ser deixada no cume de uma grande montanha e, cada vez que se aproximava do topo, a pedra rolava serra abaixo para que a tarefa fosse recomeçada. Nesse contexto, os valores simbólicos decorrentes da maneira de contar plasmam, na fita de Nelson Pereira dos Santos, significados universais, principalmente se recordarmos que o mito de Sísifo nasce do desejo de ser livre ${ }^{9}$.

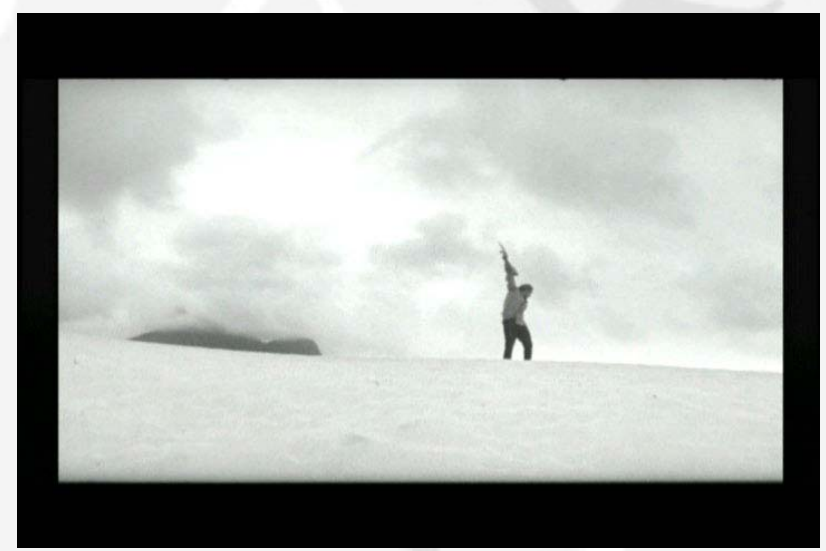

Fotograma 1

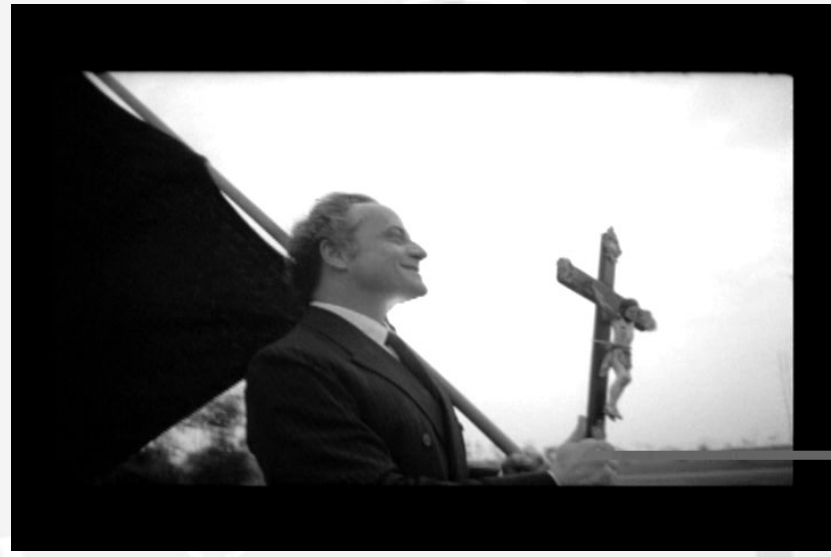

Fotograma 2

Por sua vez, em Terra em transe, os dois fotogramas acima reproduzidos concatenam, deixando de lado o prólogo da apresentação ${ }^{10}$, o plano final (1) da segunda seqüência com o plano inicial (2) da terceira. Essa combinatória gera a sensação de que o relato dá um salto. Mas a impressão se 
dissipa ao se considerar o teor das unidades semânticas constituintes da fábula, isto é, a luta, a vitória ou a derrota ${ }^{11}$. Tal dissipação deixa o espectador diante de um conflito, por exemplo, desencadeado, com auxílio da montagem, pela maneira de a narração configurar a temporalidade em cada um dos planos. De um lado, o tempo plasmado no delírio da morte de Paulo Martins e, de outro, o tempo cotidiano da vaidade mundana de quem assume o poder na figura de Porfírio Díaz. Contudo, esse embate, comparado com os que ocorrem em outras passagens do filme, antecipa a maneira fragmentária utilizada para a apresentação das ações, das personagens e da narração. Ela é, portanto, um recurso abrangente, um recurso que fragmenta tanto a expressão quanto o conteúdo e, por isso, produz constantemente um efeito de sentido que se articula numa movediça significação polivalente. Da gesticulação distante e lenta que se observa na seqüência da morte, o espectador passa a uma gesticulação congelada. A personagem representada por Paulo Autran surge, de repente, num enquadramento que reproduz a paródia teatral de iconografias palacianas $^{12}$ dos "defensores da pátria", dos "libertadores" que ficaram "imortalizados" pelos pincéis de artistas cujo discutível talento foi vergonhosamente subjugado pelas ideologias dominantes.

Em múltiplos trabalhos dedicados ao estudo da obra do cineasta brasileiro, destaca-se, no que diz respeito à narrativa, o papel que desempenham as elipses. Mas, no geral, esse recurso retórico é visto na condição de procedimento adequado à representação fragmentária, sem entrar, porém, em detalhes no que diz respeito aos efeitos que ele causa nas diferentes camadas do sistema da narrativa. Como se sabe, os críticos do Brasil e do exterior, coincidem com a premissa de que Terra em transe é, antes de qualquer coisa, um filme profundamente poético. Por isso meu interesse nas rupturas observáveis na fita, mesmo nas que se manifestam através das elipses, entendidas na condição de figuras retóricas do plano da expressão. Pretendo, assim, adentrar mais nos territórios da poesia e, conseqüentemente, necessito lidar com os modos de articulação das significações em que o poético se enforma. Desse ângulo, a elipse, no caso, arraiga na maneira de contar e mostra seus efeitos a partir do instante em que ela interfere na lógica determinante da concatenação da fábula. 
Para discutir essas questões é inevitável equacioná-las em função da diegese, embora este termo seja, no âmbito dos estudos de cinema, problemático $^{13}$. Há, por exemplo, os que defendem não pertencer à diegese músicas da trilha sonora, que mesmo fazendo parte do filme, não são

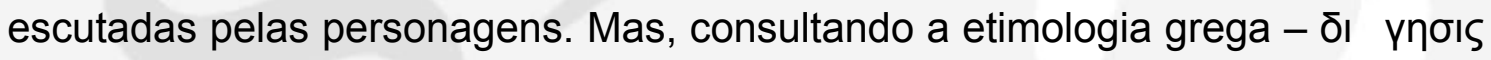
- é possível vislumbrar na trajetória desse vocábulo reminiscências de uma cultura oral antiqüíssima e relacionada com os modos de contar histórias. Creio que na retórica, quando se analisa a composição da prática oratória e das regras que a regulam, encontramos efeitos desse significado ancestral. Sem me deter no assunto, desejo apenas salientar o papel que a diegese tinha na construção de um discurso comprometido com a "arte de falar ao público". Esse construto retórico deveria seguir quatro padrões básicos: 1) uma introdução (проoímov) destinada a conquistar a empatia dos destinatários; 2)

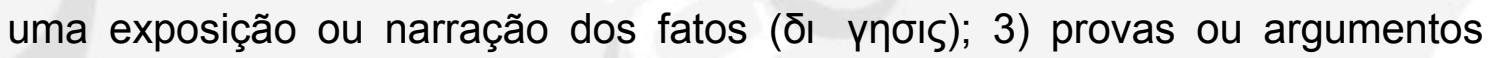

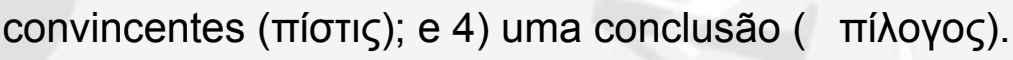

Com base nesses princípios, quer me parecer que Terra em transe mantém uma relação de intertextualidade estrutural com o discurso da oratória: tem um prólogo, uma exposição de fatos, um conjunto de argumentos e um epílogo. Nesse tipo de arranjo, a diegese tem de ser encarada como um componente dessa estrutura e, no caso, como um componente cujos sentidos alcançam a significação quando os componentes das outras partes com ela se integram. Vale dizer, portanto, que, nessa perspectiva, a diegese não é simplesmente um processo que se reporta de maneira exclusiva ao relato ${ }^{14}$, mas abrange também os outros níveis de uma narrativa; se assim não fosse, seria impossível ampliar os significados das unidades semânticas - carência, luta, vitória, prova difícil, solução preliminar etc. - de uma fábula. É preciso levar em conta ainda que, enquanto discurso, toda narrativa exige a participação de um narrador e de um narratário, modelo comunicativo que Gaudreault e Jost (1990: 46-69) matizam com a introdução dos termos meganarrador e mostrador. Além disso, o relato ou fábula - fala-se hoje em relato interativo, em relato fragmentado, em relato singulativo, em relato iterativo... - só pode ser classificado, uma vez manifestada a sua estrutura básica, em função da narração e da apresentação das personagens. Portanto, 
a diegese deve entender-se na condição de um elemento do texto fílmico sobredeterminado pelos outros níveis do sistema ou código narrativo.

Retornando, depois dessas explicações, à elipse, não será difícil constatar que, se tomarmos essa figura como parâmetro, Vida secas e Terra em transe lidam, em princípio, com a mesma fábula. Isto é, os dois filmes desenvolvem um relato em que se concatenam e ganham relevância as unidades semânticas da carência, da luta e da derrota. Mas, no tocante à diegese, as diferenças são grandes, principalmente se centrarmos nossa atenção na montagem, pois esta, enquanto narrador-fílmico, estabelece em cada uma das fitas procedimentos diferentes, procedimentos esses que repercutem no grau de ambigüidade das significações que as unidades semânticas mencionadas adquirem em cada uma das fitas. Para qualquer espectador habituado a conviver com as linguagens do cinema tal fato é evidente. Entretanto, creio que a evidência não é um dado descartável. Ao contrário, acredito que a partir dela se vislumbram horizontes que incitam a curiosidade necessária ao trabalho de leitura e interpretação, máxime quando inserimos a fábula no nível das personagens.

Fabiano, Sinhá Vitória, os meninos e a cachorra Baleia encarnam a carência, a luta e a derrota. De igual maneira, Paulo Martins encarna a carência, a luta e a derrota. Mas a caracterização dessas personagens, seu vestuário, sua gestualidade e sua posição social são diferentes e, talvez por isso, a representação que eles fazem das unidades semânticas mencionadas exija distintas modalidades de narração. Em Vidas secas, as metonímias e as sinédoques, por exemplo, escondem metáforas cujos sentidos se camuflam a partir do instante em que se desenvolvem as ações do filme e, na condição de narrador, a montagem intervém. Mas se considero os fotogramas acima reproduzidos, a sua imobilidade me faz ver a magnífica tradução poética que Nelson Pereira dos Santos fez das metáforas iniciais e finais do romance de Graciliano Ramos. No filme, as personagens iniciam sua caminhada como sombras que se deslocam lentamente na direção da câmera e, no fim, vão se afastando da câmera até se transformar de novo em sombras. Essa presença do negrume camufla, como no romance ${ }^{15}$, conotações filiadas aos conteúdos de morte agônica. 
Essas ocultações, favorecidas pelo caráter metonímico da representação fotográfica, fazem com que recursos retóricos mais sutis sejam difíceis de perceber. Acrescente-se a isso as particularidades de um tipo de montagem que, no geral, segue a linearidade cronológica dos fatos como se quisesse darIhe ainda mais transparência aos significantes fílmicos. Ou seja, a maneira de contar, embora me fundamente apenas na montagem ${ }^{16}$, deixa a sensação de que o construto fílmico foi elaborado mediante a utilização de uma retórica implícita. Isto é, de uma retórica que teria como principal finalidade suscitar no espectador a busca de significados que não se manifestam através de rupturas evidentes no plano da expressão do filme. Tenho a convicção, com base nesse pressuposto, que o filme quer ser, em termos poéticos, recatado. Tão discreto quanto o romance em que se inspira. No entanto, por trás dessa aparente obviedade, existem, no plano do conteúdo, traços de uma intensa poesia. E creio que uma das passagens que me ajuda a desempenhar melhor meu papel de narratário pode ser a que se refere à morte de Baleia.

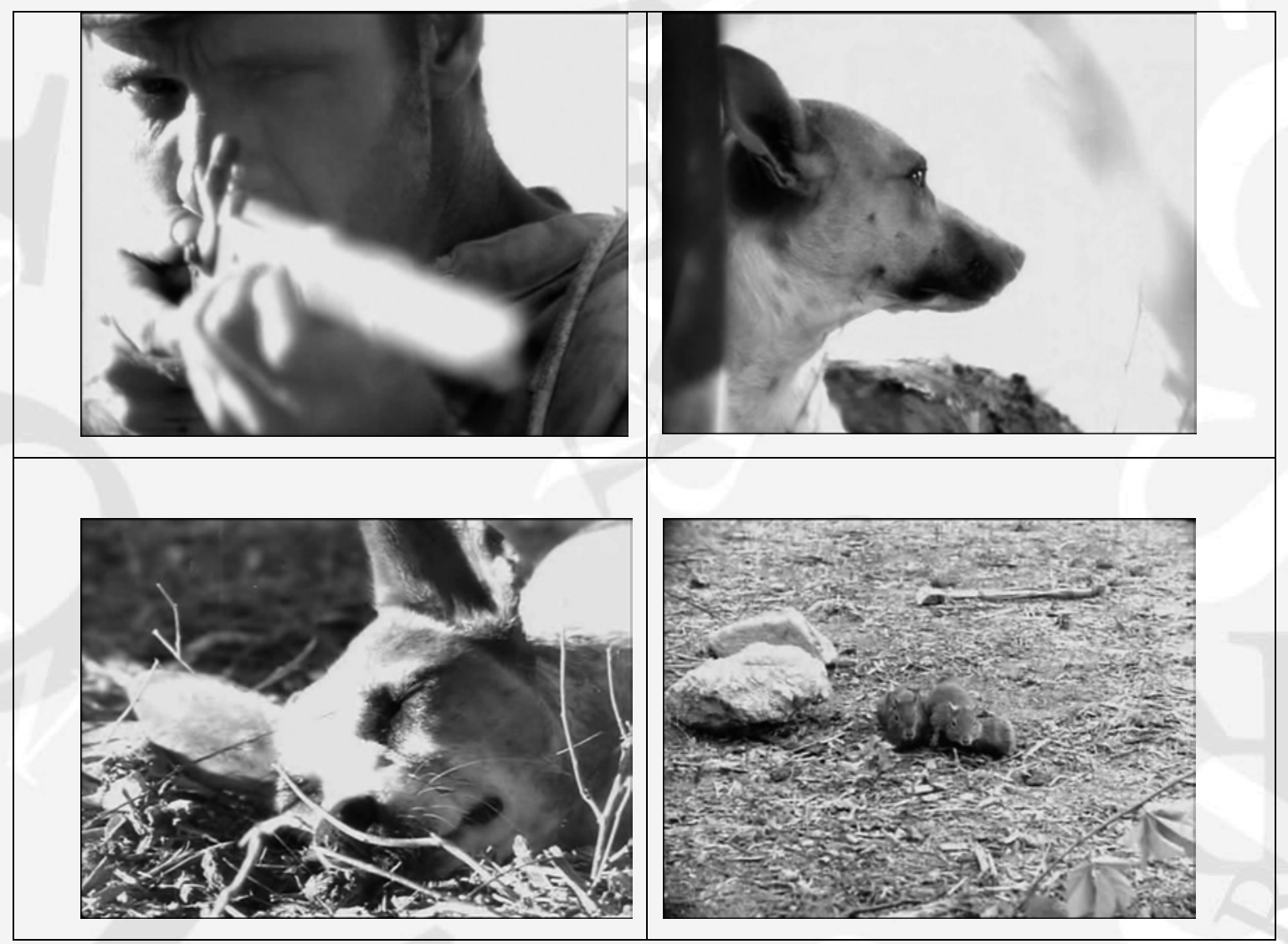


A ordenação desses quatro fotogramas reproduz planos dos momentos mais significativos da seqüência em que se representa a morte da cadela. Toda a cena parece ter sido montada em continuidade. Ou seja, seguindo cronologicamente o tempo fenomênico do acontecimento. Mas a montagem, feita através de uma combinatória de closes intercalados e planos gerais, mostra que o tempo fílmico não coincide com o tempo fenomênico. Ou, dito de outra maneira, o tempo fílmico encobre a duração "real" do episódio, o que, de modo sutil, delonga a temporalidade em benefício de ressaltar aspectos emotivos. A tensão assim criada penetra de cheio nas entranhas do narratário sem que este perceba a presença de uma ruptura no plano da expressão. Estou me referindo à passagem do close em que aparece Baleia já moribunda para um plano geral que exibe os preás correndo, livres, de um lado para outro ou olhando, com ar de triunfo, para os espectadores. Tudo indica, portanto, que o último desses planos gerais não pode se entendido como resultado de uma câmera subjetiva, pois, nesse instante, Baleia já está morta. Em todo caso, há, nessa seqüência, indícios suficientes para sentir os efeitos de uma ruptura: os roedores surgem como projeção do delírio agonizante de Baleia. Sendo assim, pertencem, por conseguinte, a um espaço imaginário que não é uma continuidade do entorno em que a cachorra agoniza.

Ancorado nessa constatação, defendo a hipótese de que nesta passagem a elipse se infiltra no texto fílmico de modo muito tênue e, em razão disso, a figura retórica determina uma ruptura por ambigüidade simples ${ }^{17}$, isto é, uma ruptura que não atenta contra as regras de funcionamento do sistema de denotação. Justamente por isso, o narratário desta seqüência não percebe, no seu primeiro contato com ela, nenhum tipo de anomalia e vê os planos dos preás na perspectiva de uma representação realista. Mas, em termos diegéticos, essa primeira impressão de leitura se desmorona quando 0 narratário se apercebe de que a montagem junta planos que não se referem a uma circunstância única. Isso fica mais patente ainda ao se constatar que da relação do filme com o romance, parte fundamental na diegese, emergem significados decorrentes da intertextualidade da narração. Desse ponto de vista, a montagem traduz da melhor maneira possível os conteúdos conotados que se insinuam no texto de Graciliano Ramos. O narrador de Vidas secas traduz com as seguintes palavras o que seria o delírio quase onírico da cadela: 
"Acordaria feliz, num mundo cheio de preás. E lamberia as mãos de Fabiano, um Fabiano enorme. As crianças se espojariam com ela, rolariam com ela num pátio enorme, num chiqueiro enorme. O mundo ficaria todo cheio de preás, gordos, enormes" (1973: 134).

A transição do plano de Baleia agonizante-morta para o plano dos preás gera, portanto, um significado que transcende a denotação, percebida numa primeira leitura do filme, e introduz nela, rompendo as aparências, toques de tenuidade por meio dos quais se manifesta uma intensa pregnância poética.

Em Terra em transe, a maneira de contar está a serviço da fragmentação do relato e seus principais recursos retóricos são apresentados de maneira explícita. O filme possui um prólogo e um epílogo e, no entremeio desses dois componentes discursivos, se situa a fábula central, alterada também no tocante à disposição das unidades semânticas. Em lugar da concatenação de carência, luta e vitória ou derrota, a fita tergiversa a ordem e, conseqüentemente, tal procedimento causa no espectador uma sensação de estranhamento. Diante dessa "confusão", o narratário tem de participar na reordenação das unidades do relato. Visto o filme, o narratário tem de reconstruir a fábula e identificar as personagens atreladas a cada uma das suas unidades, o que significa, entre outras coisas, que o espectador é obrigado a pensar, a carregar consigo imagens fantasmagóricas que se entrelaçam e desafiam o entendimento. Há passagens que se cravam nas pupilas de quem assiste à fita criando a sensação de que se memoriza um poema cujos sentidos mais fundos se desconhecem.

Não se pode negar, entretanto, que na cadeia desses insólitos arranjos surge, de vez em vez, um relato cuja significação, em que pesem as intercalações ${ }^{18}$, é facilmente decodificável. Isso ocorre, para dar um exemplo, no episódio em que o camponês grita "não desiste doutor Paulo" e pouco depois é assassinado. Apesar do valor em si desses fragmentos, eles fornecem indícios que conduzem, tortuosamente, o leitor do filme a conteúdos inesperados ou, então, à compreensão dos dilemas ideológicos do poeta Paulo Martins. De qualquer forma, o narratário precisa ver várias vezes o filme para entender uma história fragmentada pela montagem e, mesmo assim, não pode afirmar categoricamente qual seria, no âmbito da diegese, a trama que determina a fábula axial. Em todo caso, aventuro ao risco uma escolha 
ancorando-me no dado de que Paulo Martins é a personagem através da qual se manifesta de modo mais evidente a inversão das unidades da fábula já mencionadas. Desse ponto de vista e auxiliado pela forma elíptica que assume a montagem, o texto fílmico me coloca diante de um delírio que, precedendo à morte, projeta palavras e imagens numa narrativa que, como os sonhos, atenta contra a lógica, desloca ações e condensa fragmentos numa sintaxe desconcertante.

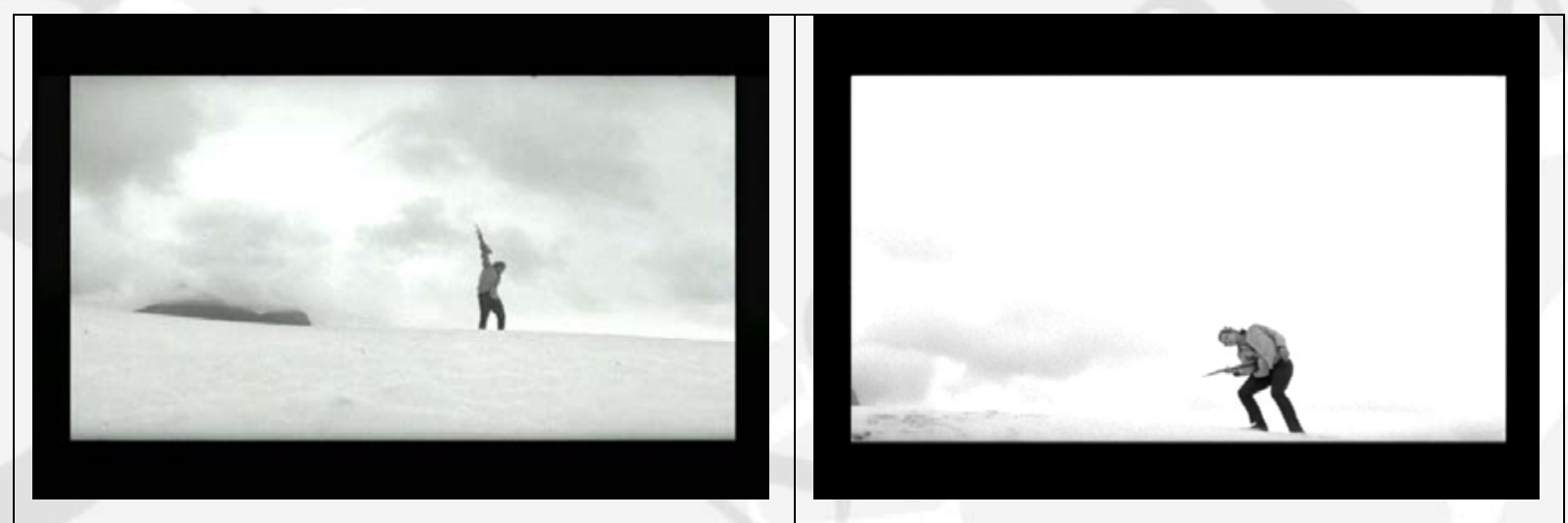

Diante desses dois fotogramas, pertencentes respectivamente a um mesmo instante diegético, mas separados no espaço do texto fílmico pela montagem, não há como negar que a eles subjaze uma espécie de planoseqüência que será fragmentado no decorrer da narrativa. O poeta Paulo Martins, já ferido mortalmente, inicia um monólogo em que se vão resumindo os transes da sua vida. Desse solilóquio, intensificado pela aridez da paisagem e pela solidão de um céu nuvioso ${ }^{19}$, o narratário escuta frases em que o poeta acentua sua vontade de cantar, suas críticas ideológicas, suas lembranças perdidas num mundo em que não é mais possível suportar uma festa de medalhas. Boa parte das frases possui um forte teor metafórico que cresce quando, em outras passagens do filme, também fragmentadas, ouvem-se muitas das suas palavras. Há momentos em que Porfírio Díaz ${ }^{20}$ parece mimar a fonética dessas frases com o movimento dos lábios, como se estivesse pronunciando o discurso que o poeta queria ouvir e, logo a seguir, soam como marteladas ditatoriais as palavras deste político que imagina ser imperador ${ }^{21}$. 


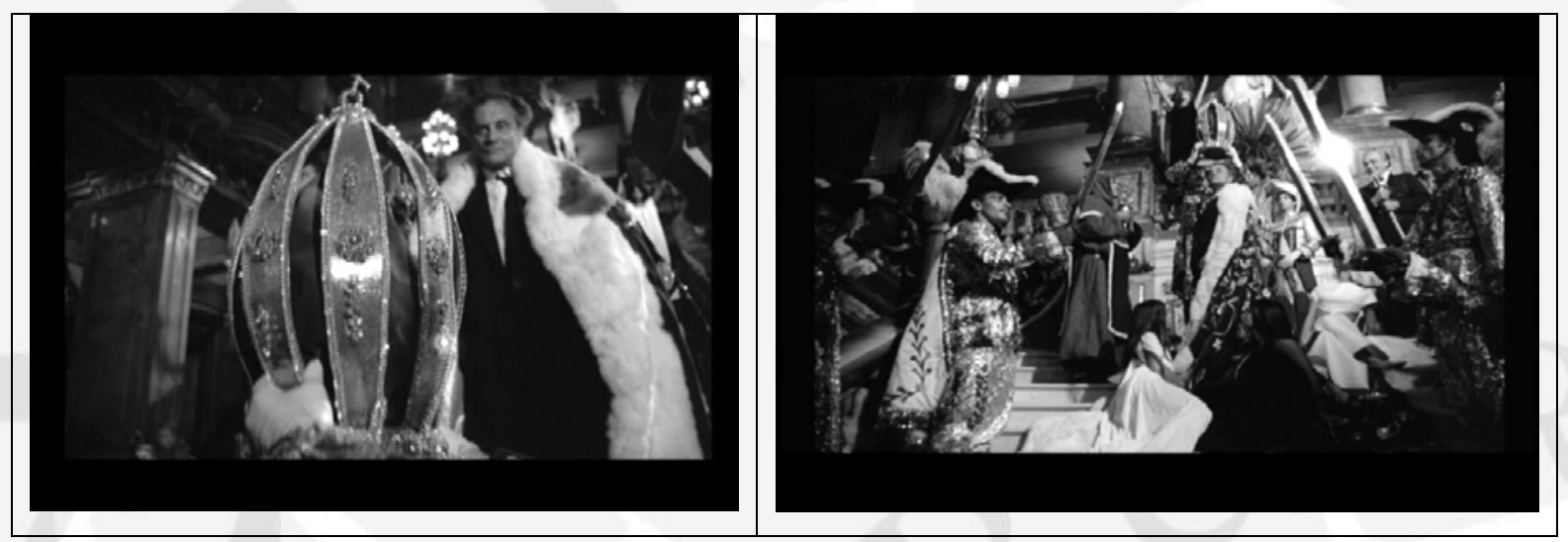

As ocorrências que se imiscuem na seqüência da "coroação", vistas em conexão com outras intercalações freqüentes em todo o texto fílmico, configuram um procedimento de flashback cujas numerosas intermitências apresentam, sem ordem cronológica definida, a trajetória existencial do poeta Paulo Martins. Esse artifício não só fragmenta o relato e a atuação da personagem que encarna a abrangência significativa das unidades semânticas da fábula, mas serve, também, para encenar ações destinadas a mostrar a interioridade do poeta ${ }^{22}$. Em razão disso, creio que o tipo de montagem posto em prática em Terra em transe tem, no âmbito da narração ou maneiras de contar, uma clara função metalingüística. Ou seja: enquanto a montagem, através de recursos elípticos, gera ambigüidade, o narratário tem de reconstruir o relato reorganizando a história a partir dos indícios que essa função metalingüística Ihe propicia.

Esse recurso poético, auxiliado por outros que aqui deixo de lado, é suficiente para captar, de um lado, a opacidade do texto fílmico, e, de outro, a modalidade de ruptura que se manifesta no plano de expressão da fita. A elipse, definida como omissão de componentes sintáticos, obriga o leitor a lidar com subentendidos, é, portanto, um processo retórico necessário à emergência de ambigüidades acolhedoras do poético. Mas, além disso, a elipse, ao atentar contra lógica da sintaxe e da gramática fílmicas, engendra ambigüidade tanto no plano do conteúdo quanto no plano da expressão. Vale dizer, por conseguinte, que a ambigüidade expressiva amplia a ambigüidade do conteúdo. Em outras palavras, a elipse, em Terra em transe, não recai apenas 
sobre a narração da montagem. Recai, também, sobre a manipulação de outros muitos códigos presentes no filme de Glauber Rocha: teatralidalidade, gestualidade, sonoplastia ${ }^{23}$, pintura, vestuário etc. Tudo isso contribui para estender os efeitos poéticos da elipse e, baseando-me nisso, acredito que a ruptura preponderante no filme é uma ruptura por dupla ambigüidade.

Em suma, creio que este trabalho deve ser lido como uma introdução à manifestação de recursos poéticos em duas obras relevantes do Cinema Novo. Dessa perspectiva, espero que assim seja entendido pelos eventuais leitores, pois, no fundo, minha intenção não vai além da formulação de uma alternativa ainda pouco explorada. 
BARTHES, Roland. La chambre claire. Paris: Seuil, 1980.

DENTITH, Simon. Parody. Londres: Routledge, 2000.

GAUDREALT, André \& JOST, François. El relato cinematográfico. Cine y narratología. Barcelona: Paidós, 1995.

BRANIGAN, Edward. Narrative comprehension and film. Londres: Routledge, 1992.

LOPES, Edward \& PEÑUELA CAÑIZAL, Eduardo. O mito e sua expressão na literatura hispano-americana. São Paulo: Duas Cidades, 1982.

MONTEIRO, Ronald T. "Nelson Pereira dos Santos". In: Le cinéma brésilien. Paris: Centre Pompidou, 1987.

PEÑUELA CAÑIZAL, Eduardo. Duas leituras semióticas. São Paulo: Perspectiva, 1977.

. "El otro lado de la metáfora en La Vía Láctea". In: SANTAOLALLA, Isabel \& EVANS, Meter W. (eds.). Buñuel, Siglo XXI. Zaragoza: Prensas Universitarias, 2004, p. 379-396.

RAMOS, Graciliano. Vidas secas. 31ª ed. São Paulo: Martins, 1973.

XAVIER, Ismail. "Glauber Rocha: le désir de l'Histoire". In: Le cinéma brésilien. Paris: Centre Pompidou, 1987.

. Alegorias do subdesenvolvimento. São Paulo: Brasiliense, 1994.

\footnotetext{
${ }^{1}$ Este trabalho está vinculado à pesquisa que estou desenvolvendo com bolsa do CNPq. Uma versão condensada do texto foi publicada no livro Estudos Socine de Cinema VIII (São Paulo: Annablume, 2007).

${ }^{2}$ Professor da Universidade de São Paulo (USP) e Universidade Paulista (Unip)

${ }^{3}$ Menciono apenas um par delas. Ismail Xavier diz que, em Terra em transe, a "mise en scène de la trame politique mobilise les figures qui personnifient les forces sociales, figures qui parlent le langage des intérêt de classe ou du jeu du pouvoir arbitré par le capital. Il y a une préoccupation à la Brecht d'exposer les contradictions d'Eldorado, pays allégorique. Mais il y a aussi une confluence de gestes, un défilé de masques grotesques, un conflit de charismes, une obstination magique de part et d'autre dans la confrontation entre droite et gauche..." (1987, p. 146). Ronald F. Monteiro, referindo-se a Vidas secas, afirma que o "ton journalistique de Nelson Pereira dos Santos (ne pas confondre journalisme et reportage), dans la dramatisation de la vie des retirantes, surprit par la combinaison de l'économie des informations et la densité de la problématique" (1987, p. 158).

${ }^{4}$ Há críticos que defendem o princípio de que neste filme a narrativa não é linear. Não entrarei nessa discussão aqui, apenas me limito a trabalhar com o pressuposto de que o relato, em seu conjunto, é linear.

${ }^{5}$ Já tratei deste assunto, em meu livro Duas leituras semióticas, ao estudar os modos de que se serve Graciliano Ramos para construir a narrativa to texto fílmico de Vidas secas (Peñuela Cañizal, 1977, p. 3152).
} 
${ }^{6}$ Os dicionários definem o termo carência como significando: falta, necessidade, privação.

${ }^{7}$ Não se pense que, quando digo "poético", estou esquecendo o contexto social ou sou indiferente à ideologia política criticada pelo filme. Ao contrário. O que pretendo ressaltar é que o poético é um instrumento das linguagens para penetrar mais fundo na representação do social ou de ideologias que ceifam a ilusão de liberdade necessária à sobrevivência de qualquer ser humano jogado, sem "prévio aviso", na labuta existencial.

${ }^{8}$ Enquanto disciplina, a narratologia começa a ganhar corpo com os estudos estruturais feitos por Propp sobre o conto popular russo e por Lévi-Strauss sobre os mitos. Cresceu com os pensadores da Escola de Tartu e com os semioticistas da chamada Escola de Paris. A fase estruturalista cedeu passo a outras formulações e, no contexto atual, os autores que contribuíram para a renovação de velhos modelos são, sem dúvida, Gaudreault e Jost. É de se reconhecer também a importância de Branigan e Bordwell.

${ }^{9}$ Admitidos esses valores simbólicos e as conotações que já se cristalizaram no linguajar comum, não me parece descabido afirmar que a produção cinematográfica de Vidas secas foi fruto de um "trabalho de Sísifo", assim como as produções de quase todos os filmes do Cinema Novo. Esse dado é bem significativo quando relacionado ao contexto político da época em que foram realizados ou, mesmo, às idéias do existencialismo espalhadas na década de 1960.

${ }^{10}$ A apresentação funciona como prólogo e, em muitos aspectos, se assemelha aos prólogos de filmes de Luis Buñuel e, em certa medida, esse fragmento pode ser visto, nos jogos intertextuais do imaginário, como um curioso antecedente de La voie lactée (1969). Faço essa sugestão porque, revendo o filme de Glauber Rocha e o estudo que já fiz do prólogo da fita de Buñuel (Peñuela Cañizal, 2004), tenho para mim que as relações intertextuais entre os dois prólogos enriquecem a leitura de cada um dos filmes.

${ }^{11}$ Essas unidades semânticas se unem mediante a intervenção do que se poderia chamar uma lógica simbólica. Em outras palavras, o valor de cada uma das unidades é relativo e depende, em primeira instância, da ideologia representada pelas personagens que as encarnam. Assim, a morte vista como derrota do ser humano no mundo pode ser vista, numa ideologia revolucionária, como vitória. A esse respeito, as palavras ditas pelo protagonista do filme são esclarecedoras: "Não se faz a revolução com lágrimas...”.

${ }^{12}$ Ismail Xavier se refere a essa iconografia na entrevista que consta do DVD especial do filme lançado recentemente. Além disso, a dimensão alegórica que subjaze a essas iconografias é analisada também por esse crítico no livro Alegorias do subdesenvolvimento (1993). Mas, sobre este assunto, seria conveniente alargar o alcance dos conteúdos alegóricos das iconografias palacianas fazendo-as dialogar com as obras dos muralistas mexicanos. Julgo que esse diálogo, levando em conta que o diretor de Terra em transe declara em várias oportunidades a abrangência latino-americana de seu filme, é imprescindível se queremos analisar a obra de Glauber Rocha no contexto cultural da intertextualidade e no papel paródico que ela desempenha. E, quando digo paródico, estou entendo o termo à maneira de Simon Dentith ao afirmar que "parody is one of the many forms of intertextual.allusions out of which texts are produced" (2000, p. 6).

${ }^{13}$ Esta palavra tem acepções muito diversas em autores como Gentette, Hawthorn, Metz, Barthes, Jost e outros muitos que poderiam ser incluídos nessa pequena lista.

${ }^{14} \mathrm{O}$ termo "relato" é designado de diversas maneiras em línguas diferentes: argumento, plot, fábula, récit, fable, story etc. A esse respeito e utilizando uma definição de diegese, julgo oportuno citar a seguinte passagem: "Para caracterizar este universo construido por la película, y que es ampliamente mental, Souriau ha propuesto el término diégesis, que define de la siguiente manera: 'Todo lo que pertenece, dentro de la inteligibilidad de la historia relatada, al mundo propuesto o supuesto por la ficción' (Souriau, 1953, p. 7). En este contexto, daremos al término historia un sentido más restringido que anteriormente: la serie cronológica de los acontecimientos relatados, por oposición a relato, que es la manera de contarlos" (Gaudreault e Jost, 1990, p. 42-43). Com o intuito de precisar a terminologia que aqui emprego, e sem que isso signifique discordância com o pensamento desses autores, fábula e relato são para mim sinônimos. Reconheço, porém, que o termo história (story), argumento ou relato surgem quando as unidades da fábula se articulam no nível das personagens e, por conseguinte, já possuem traços gerais da narração.

${ }^{15} \mathrm{O}$ termo "sombra" é reiterado constantemente no romance. E em cada contexto da reiteração significa algo relacionado com significados ilusórios ou fatais. Dessa dicotomia surge um conteúdo que sugere que a vida e a morte dialogam a cada instante. A esse respeito, é relevante a conotação de que se impregna o pensamento de Fabiano quando o narrador nos diz que o vaqueiro ensombra-se com a idéia de que se dirigia a terras onde não houvesse gado para tratar.

${ }^{16}$ Dada a natureza deste trabalho, não acho conveniente deter-me em outros elementos da narração, tais como, por exemplo, a relação entre narração e enunciação, o papel de meganarrador e do mostrador ou mesmo seguir o modelo de Branigan (1992, p. 13-20). Isso pressuporia a realização de um trabalho de 
mais envergadura, embora reconheço que o pensamento desses autores daria mais consistência a minhas interpretações.

${ }^{17}$ Sobre a ruptura por ambigüidade simples e por dupla ambigüidade ver Lopes e Peñuela Cañizal (1981, p. 119-142).

${ }^{18}$ Convém lembrar que este episódio começa no momento em que Filipe Vieira, candidato, dialoga com o povo afetuosamente, inclusive com o camponês que mais adiante será assassinado.

${ }^{19}$ Fixando o olhar da fantasia e da imaginação nas nuvens representadas no primeiro fotograma, talvez não seja um excesso de idéia afirmar que nesse céu se configuram arcimbolescamente mapas dos continentes americano, europeu e africano. Tal observação não deve ser tão gratuita em razão de que o prólogo e o epílogo do filme se servem, em certa medida, da cartografia e também porque essas nuvens me "pungem", como diz Barthes quando, em La chambre claire (1980), tenta definir o punctum de uma fotografia.

20 Vale a pena lembrar que Porfírio Díaz, homônimo da personagem de Glauber, foi um ditador mexicano, muitas vezes citado por ter dito: "Pobre México! Tão longe de Deus e tão perto dos Estados Unidos!". Existe também uma menção importante à cultura latino-americana: Paulo Martins declama uma estrofe do poema Martín Fierro, de José Hernández.

${ }^{21}$ Os gestos são típicos dos ditadores latino-americanos, mas fica a dúvida quanto à iconografia: ela faz parte da realidade da personagem ou traduz visualmente o arrebatamento de quem se julga um novo Napoleão?

${ }^{22}$ Uma das mais relevantes no que tange às atitudes ideológicas de Paulo Martim aparece no encontro e na luta que ele mantém, no interior do palácio, com Porfírio Díaz.

${ }^{23}$ Aliás, a trilha sonora, tal como estruturada, intensifica ainda mais o papel poético da elipse. Basta recordar, por exemplo, a sonoridade das palavras quando separadas de quem as diz, que aparecem em outras passagens e se impregna de significados cuja ressonância, no filme, é pregnante. Outro tanto ocorre na seqüência da "coroação", quando escutamos os disparos consecutivos de metralhadora. 